\title{
Inoculum Sources of Botrytis cinerea Important to Pear Orchards in Oregon
}

\author{
Robert A. Spotts and Maryna Serdani, Oregon State University Mid-Columbia Agricultural Research and Exten- \\ sion Center, Hood River 97031
}

\begin{abstract}
Spotts, R. A., and Serdani, M. 2006. Inoculum sources of Botrytis cinerea important to pear orchards in Oregon. Plant Dis. 90:750-754.

Botrytis cinerea was capable of colonizing and persisting in tissue pieces of six common weed species found in pear orchards in Oregon from midsummer until pear harvest in early September. Sporulation occurred on blackberry mummies in orchard perimeters and ranged from 5,700 to 55,000 conidia per mummy at pear harvest. Conidia of $B$. cinerea also were observed on fresh blackberry fruit in 2 of 3 years. Sclerotia were present on only a few of the naturally infected pear fruit on the orchard floor through November; however, sclerotia production increased greatly between mid-November and mid-December. Over $90 \%$ of sclerotia from naturally infected, overwintered fruit germinated in the laboratory when collected 6 to 8 months after infection. Sclerotia formed on pear fruit inoculated with 28 different paired combinations of 22 isolates in the laboratory. Viability of sclerotia in inoculated pear fruit that overwintered on the orchard floor was 44 to 59\% in March and April, and then declined steadily to about $25 \%$ at pear harvest. Germination of sclerotia was both sporogenic and myceliogenic. No apothecia were observed in the field or laboratory. An integrated approach to control is needed to deal with these multiple sources of potential inoculum.
\end{abstract}

Additional keywords: gray mold

Botrytis cinerea Pers.:Fr. is responsible for a significant portion of postharvest losses incurred by the pear packing industry of the Pacific Northwest $(14,20,22)$. Propagules of $B$. cinerea are found in soil, plant litter, air $(7,17)$, and packinghouse dump tank water $(1-3,22)$. It is generally assumed that the initial inoculum originates in the pear orchard (7), but specific inoculum sources have not been studied.

$B$. cinerea is a cosmopolitan, necrotrophic fungus that colonizes almost any senescing or dead plant material (18). Host genera listed for $B$. cinerea number at least 245 (10) and include many common weed species. In most pear orchards in the $\mathrm{Pa}-$ cific Northwest, herbicides are used to control weeds in the tree rows, but grasses and various broadleaf weeds grow in the row middles. Senescing or mowed weeds are susceptible to $B$. cinerea; however, the relative importance of the various weed species in pear orchards as inoculum sources is unknown. Among weeds common to California almond orchards, filaree

Corresponding author R. A. Spotts

E-mail: robert.spotts@ oregonstate.edu

Use of trade names in this article does not imply endorsement by Oregon State University of the products named or criticism of similar products not mentioned.

Accepted for publication 9 January 2006.

DOI: 10.1094/PD-90-0750

(C) 2006 The American Phytopathological Society and shepherds purse are most susceptible to $B$. cinerea, whereas common chickweed and annual bluegrass are the least susceptible (R. Elkins, personal communication).

Many pear orchards in the higher rainfall districts close to the Cascade Mountains are bordered by hedges of wild blackberry (Rubus discolor Weihe \& Nees). B. cinerea is the most common pathogen of Rubus spp. worldwide (4) and frequently infects blackberry fruit in the Willamette Valley in Oregon (13). The importance of wild blackberry as a source of inoculum of $B$. cinerea in the drier Hood River Valley of Oregon is not known.

Sclerotia generally are considered to be the most important structures involved in the survival of Botrytis spp. (5). On raspberry and blackberry, conidia arising from sclerotia and mycelia are the main source of primary inoculum (4). Sclerotia are a source of primary inoculum for bunch rot of grapes in Australia, and sporogenic germination leads to infection of flowers and berries (19). Sclerotia also are an important part of the disease cycle of $B$. cinerea on numerous floral, vegetable, and greenhouse crops. However, their importance in pear orchards has not been studied.

The objectives of this study were to determine (i) persistence of B. cinerea on six weed species common to pear orchards in Oregon, (ii) infection and sporulation of $B$. cinerea on wild blackberry mummies bordering pear orchards, and (iii) sclerotia production and viability on naturally in- fected and inoculated pear fruit on the orchard floor.

\section{MATERIALS AND METHODS}

Persistence of $B$. cinerea on common weed species. Colonization and persistence of $B$. cinerea was determined on tissue of six weeds common to pear orchards in the Hood River Valley. Leaves and stems of white sweet clover (Melilotus alba Medikus.), annual bluegrass (Poa annua L.), common chickweed (Stellaria media (L.) Vill.), common mallow (Malva neglecta Wallr.), quackgrass (Elymus repens (L.) Gould), and dandelion (Taraxacum officinale G. H. Weber ex Wiggers) were collected in 4-liter polyethylene bags on 21 June 2002 and 19 June 2003. In addition to weeds, dead pear leaves also were collected. Leaves and stems of each species were triple sterilized as follows: $95 \%$ ethanol for $30 \mathrm{~s}, 0.525 \%$ sodium hypochlorite for $2 \mathrm{~min}$, and $95 \%$ ethanol for $30 \mathrm{~s}$. Surface-sterilized weed tissue was placed in sealed plastic boxes and held for 3 days at $22^{\circ} \mathrm{C}$ to give tissue time to begin to senesce. Before inoculation, tissue of each species was dipped in $95 \%$ ethanol, dried in a laminar flow air bench, and cut into pieces about 5 by $5 \mathrm{~mm}$ (leaves) or 5 $\mathrm{mm}$ long (stems). Tissue was inoculated by immersing it into an aqueous suspension containing $B$. cinerea isolate 62 at 50,000 conidia/ml, harvested from 14-day-old cultures grown on potato dextrose agar acidified with $1.5 \mathrm{ml}$ of lactic acid per liter (APDA). Inoculated tissue was place into sealed plastic boxes at $22^{\circ} \mathrm{C}$ for 2 to 3 days to allow $B$. cinerea to colonize the tissue. Colonized tissue pieces were placed into cheesecloth pieces (each 10by $-15 \mathrm{~cm}$ ) which were folded in half and stapled to make envelopes. For each plant species, 24 envelopes were filled with 30 pieces of tissue per envelope. The 24 envelopes were placed between trees in a d'Anjou pear orchard at the MidColumbia Agricultural Research and Extension Center (MCAREC), Hood River, $\mathrm{OR}$, and held in place with a nylon screen. Four envelopes per species were collected each month, and tissue pieces plated on APDA. The first isolation (0 month) was done the same day that tissue pieces were placed in the envelopes prior to placement in the orchard. Plated tissue pieces were examined after 5 to 7 days for growth of $B$. cinerea.

Infection and sporulation of $B$. cinerea on wild blackberry mummies. Blackberry fruit mummies (dried fruit 
from the previous season still attached to the canes) were collected monthly beginning in May from three locations near pear orchards at MCAREC. The locations were about 300 to $400 \mathrm{~m}$ apart, along the perimeters of pear orchards about $5 \mathrm{~m}$ from the nearest trees. In all, 100 mummies from each location were triple sterilized as described above. Mummies were plated on APDA, four mummies per plate. Mummies were examined after 4 to 7 days of incubation at $22^{\circ} \mathrm{C}$ and incidence of colonization by $B$. cinerea was calculated. In addition, 100 from each location were divided into four groups, each with 25 mummies, weighed, then placed in $30 \mathrm{ml}$ of sterile distilled water with 1 drop of Tween 80 . Mummies were shaken $10 \mathrm{~min}$ at $160 \mathrm{rpm}$ on a rotary shaker, then sonicated for 10 $\mathrm{min}$. Conidia of $B$. cinerea in the wash water were counted with the aid of a hemacytometer. Numbers of conidia per mummy were calculated. At each location, 100 fresh berries were evaluated visually for infection and sporulation at the time of pear harvest.

Natural gray mold infection and sclerotia production on fallen pear fruit. An orchard of d'Anjou pear trees at MCAREC was selected to determine the percentage of fruit on the ground after harvest that was infected with $B$. cinerea and the percentage of infected fruit with sclerotia. Starting on 11 November 2000 and 15 October 2001, about 2 and 1 months after harvest, respectively, d'Anjou pear fruit that had fallen to the ground during harvest were inspected visually for gray mold infection and presence of sclerotia. Between 500 and 800 fruit per inspection were observed in 2000 and from 250 to 350 fruit per inspection in 2001. Fruit were inspected three times until mid-December each year.

Viability of overwintered sclerotia on naturally infected pear fruit. Five sites were selected in December 2000 and three sites in December 2001 in a pear orchard at MCAREC to determine sclerotia viability. Each site of about $900 \mathrm{~cm}^{2}$ had two to four d'Anjou pear fruit that were naturally infected with $B$. cinerea and had sclerotia on the fruit in December. Starting in May 2001 and July 2002, $200 \mathrm{~g}$ of soil and litter from the top $5 \mathrm{~cm}$ were collected at each site in the area where the fruit had decomposed. Samples were placed in a twin shell blender and mixed for $1 \mathrm{~h}$. Three mixed, 10 -g subsamples from each site were washed through a sieve (2-mm mesh) with $400 \mathrm{ml}$ of distilled water to remove larger debris, then through a $1-\mathrm{mm}$ sieve to remove all soil and debris smaller than 1 $\mathrm{mm}$. Soil and litter containing sclerotia that were trapped on the $1-\mathrm{mm}$ mesh were transferred to petri dishes containing APDA. Dishes were incubated at $22^{\circ} \mathrm{C}$ and examined after $20 \mathrm{~h}$ with a dissecting microscope. Sclerotia were transferred to clean APDA dishes to reduce interference from other microbes, and the total number of sclerotia and number of germinated sclerotia were counted after an additional $20 \mathrm{~h}$.

Sclerotia production and viability in pear fruit inoculated with paired isolates. Isolates of $B$. cinerea were collected from 1996 to 1998 as part of a previous study (15). In all, 22 isolates were selected that included 7 that did not produce sclerotia on APDA and 15 that produced sclerotia. Isolates were from five locations in the Hood River Valley (14 isolates), one location at Mount Adams, WA (3 isolates), and three locations in the Wenatchee district, WA (5 isolates). d'Anjou and Bartlett pear fruit were surface sterilized with so- dium hypochlorite at $100 \mathrm{ppm}$, rinsed with distilled water, and inoculated. For each isolate, 2-by-2-mm pieces of mycelium from the margins of 5- to 7-day-old APDA cultures were placed into wounds on the stem-calyx axis about $5 \mathrm{~cm}$ apart. The 22 isolates were paired in 28 different combinations, and each combination was inoculated into three d'Anjou and three Bartlett fruit in 2000 and 2001. Inoculated fruit were sealed in polyethylene bags and incubated in the dark at $15^{\circ} \mathrm{C}$ for 3 weeks, then at $5^{\circ} \mathrm{C}$ for 2 additional weeks. In 2000, d'Anjou and Bartlett fruit were inoculated on 1 and 14 August, respectively. In 2001, both cultivars were inoculated on 31 August. After the 5-week incubation,
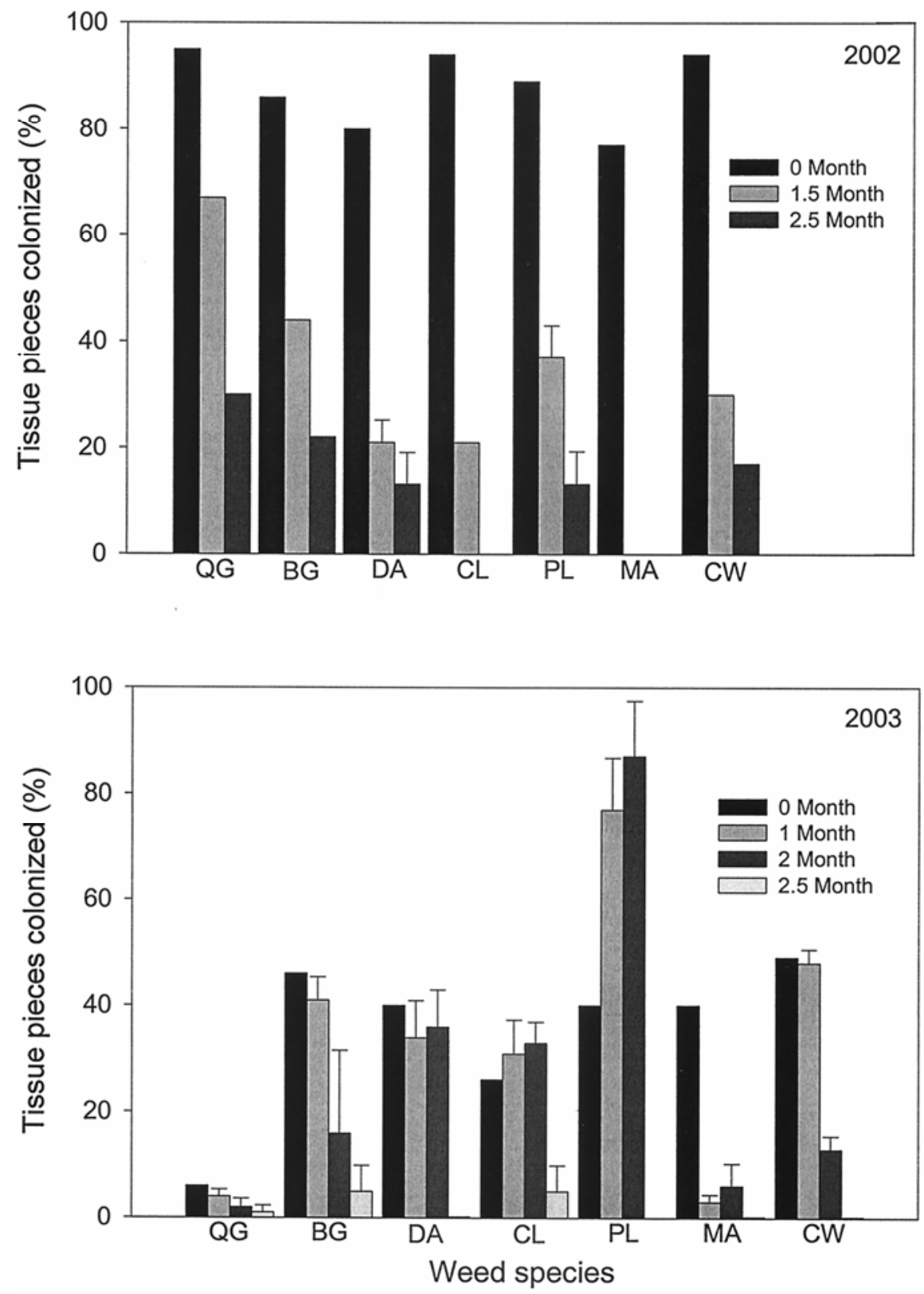

Fig. 1. Colonization and persistence of Botrytis cinerea in major weed species from pear orchards in 2002 and 2003. On 26 June 2002 and 25 June 2003, isolations were done from pieces of inoculated tissue $(0$ month), and remaining pieces were placed in the orchard on 26 June of both years. QG = quackgrass, BG $=$ annual bluegrass, $\mathrm{DA}=$ dandelion, $\mathrm{CL}=$ white sweet clover, $\mathrm{PL}=$ dead pear leaves, $\mathrm{MA}=$ common mallow, and $\mathrm{CW}=$ common chickweed. Bars show standard error of the means derived from three to four observations. Standard errors were not calculated for less than three observations. 
the number of sclerotia on each fruit was counted.

After sclerotia were counted, fruit were placed in wire baskets lined with nylon mesh. The nylon was stapled shut to exclude insects, and the baskets were placed in the tree row of a pear orchard at MCAREC. Soil and litter were loosened, weeds removed, and the bottom $2 \mathrm{~cm}$ of the basket and fruit were pressed into the loose soil and litter to cover the fruit surfaces where sclerotia density was greatest. In 2000, d'Anjou and Bartlett fruit were placed in baskets in the orchard on 5 and 19 September, respectively. In 2001, all fruit were placed in the orchard on 3 October. From March to July 2001 and May to September 2002, six sclerotia were removed monthly from each fruit. Sclerotia were surface sterilized with $95 \%$ ethanol for $20 \mathrm{~s}$ and $0.525 \%$ sodium hypochlorite for $20 \mathrm{~s}$, followed by $95 \%$ ethanol for $20 \mathrm{~s}$. Sclerotia were plated on APDA and evaluated for germination after 20 and $40 \mathrm{~h}$ at $22^{\circ} \mathrm{C}$.

\section{RESULTS}

Persistence of $B$. cinerea on common weed species. Tissue pieces in many of the envelopes were lost to insects and decomposition, and isolations were done 1.5 and 2.5 months after placement in the orchard in 2002 or after 1,2 , and 2.5 months in 2003 . Initial recovery ( 0 month) of $B$. cinerea from inoculated tissue pieces ranged from 77 to $95 \%$ in 2002 and 6 to $49 \%$ in 2003 (Fig. 1). In 2002, recovery of B. cinerea was highest from quackgrass after 1.5 and 2.5 months at 67 and $30 \%$, respectively (Fig. 1). Just before pear harvest at the end of August (1.5 month), quackgrass and annual bluegrass had the highest percent tissue with $B$. cinerea. Recovery from other weed species after 2.5 months was similar and ranged from 13 to $22 \%$. Envelopes containing mallow and clover tissue pieces were infested with insects and earthworms that consumed the tissue. In 2003, recovery immediately prior to pear harvest (2 month) ranged from 2 to $36 \%$ for weed species and was $87 \%$ for dead pear leaves (Fig. 1). By mid-September, $B$. cinerea was recovered in only 0 to $5 \%$ of the weed tissue pieces. Pear leaves had decomposed and none were left to evaluate.

Infection and sporulation of $B$. cinerea on wild blackberry mummies. Infection of blackberry mummies varied with location and year but often exceeded $75 \%$ (Table 1). Immediately prior to pear harvest in late August, 4 to $89 \%$ of mummies were infected. Sporulation on mummies was greatest in May and June and decreased in July and August (Table 1). Nevertheless, over 55,000 conidia per mummy were found in August 2002 and from 1,992 to 5,703 conidia per mummy in August 2003. At pear harvest time, no sporulation was observed on fresh, current-season berries in 2001, but sporulation on fresh berries ranged from 2 to $22 \%$ in 2002 and 2003.

Natural gray mold infection and sclerotia production on fallen pear fruit. Percent of d'Anjou fruit with gray mold observed on the orchard floor after harvest varied each year (Table 2). Most infections were at wound sites, many caused by rodent feeding. Sclerotia were present on only a few of the infected fruit through November, but sclerotia production increased greatly between mid-November and mid-December in both years.

Viability of overwintered sclerotia on naturally infected pear fruit. Over $90 \%$ of sclerotia from infected, overwintered fruit germinated when collected 6 to 8 months after infection and placed on dishes of APDA in the laboratory (Table 3). Germination was both sporogenic and myceliogenic. No apothecia were observed in the field or laboratory.

Sclerotia production and viability in pear fruit inoculated with paired isolates. Sclerotia formed on pear fruit inoculated with all 28 pairings of isolates (Table 4). Sclerotia production varied considerably and no pairing was consistently most productive. Overall, isolates that produced no sclerotia on APDA also produced the least sclerotia on fruit. More sclerotia were formed on Bartlett than on d'Anjou fruit. More sclerotia were produced on fruit inoculated in 2000 than in 2001 (Table 4).

Viability of sclerotia in inoculated pear fruit that overwintered on the orchard floor was 44 to $59 \%$ in March and April, then declined steadily through July 2001 (Table 5). In 2002, no clear pattern of viability was observed from May through September. Viability ranged from 17 to $47 \%$, except for sclerotia from d'Anjou fruit in September that had only $5 \%$ viability. Several isolates were lost after the 2001 inoculations and could not be repeated in 2002. Germination of sclerotia in the orchard was observed on 6 to $23 \%$ of the isolate pairings in April and May, but no germination in the orchard occurred in June through September. Germination was sporogenic and myceliogenic, and no apo-

Table 2. Gray mold and sclerotia on d'Anjou pear fruit on the orchard floor after harvest ${ }^{\mathrm{a}}$

\begin{tabular}{lcc}
\hline Date & $\begin{array}{c}\text { Infected } \\
\text { fruit (\%) }\end{array}$ & $\begin{array}{c}\text { Infected fruit with } \\
\text { sclerotia (\%) }\end{array}$ \\
\hline 2000 & & \\
November 11 & 54 & 2 \\
December 7 & 94 & 19 \\
December 21 & 58 & 21 \\
2001 & & \\
October 15 & 14 & 0 \\
November 15 & 22 & 4 \\
December 14 & 25 & 35 \\
\hline
\end{tabular}

${ }^{a}$ Means based on 500 fruit for each sampling date in 2000 and 346, 317, and 250 fruit on 15 October, 15 November, and 14 December 2001, respectively.

Table 3. Viability of overwintered sclerotia from naturally infected pear fruit ${ }^{\mathrm{a}}$

\begin{tabular}{lccccc}
\hline & \multicolumn{2}{c}{$\begin{array}{c}\text { Total no. of } \\
\text { sclerotia per } \\
\text { 100 g of dry soil }\end{array}$} & & \multicolumn{2}{c}{$\begin{array}{c}\text { } \\
\text { Sclerotia } \\
\text { germinated (\%) }\end{array}$} \\
\cline { 2 - 3 } \cline { 5 - 6 } Month & $\mathbf{2 0 0 1}$ & $\mathbf{2 0 0 2}$ & & $\mathbf{2 0 0 1}$ & $\mathbf{2 0 0 2}$ \\
\hline May & 34 & ND & & 95 & ND \\
June & 50 & ND & & 98 & ND \\
July & 37 & 55 & & 91 & 93 \\
\hline
\end{tabular}

${ }^{a}$ Sclerotia recovered from top $5 \mathrm{~cm}$ of soil and litter. $\mathrm{ND}=$ not determined.

Table 1. Botrytis cinerea incidence and sporulation on wild blackberry mummies near pear orchards in Hood River, OR ${ }^{\mathrm{a}}$

\begin{tabular}{|c|c|c|c|c|c|c|}
\hline \multirow[b]{2}{*}{ Month } & \multirow[b]{2}{*}{ Location $^{\text {b }}$} & \multicolumn{3}{|c|}{ Mummies infected (\%) } & \multicolumn{2}{|c|}{ Number of conidia per mummy } \\
\hline & & 2001 & 2002 & 2003 & 2002 & 2003 \\
\hline May & A & ND & ND & $79 \pm 5$ & ND & $515,250 \pm 106,513$ \\
\hline \multirow{3}{*}{ June } & A & $83 \pm 6$ & ND & $36 \pm 5$ & ND & $321,375 \pm 178,668$ \\
\hline & $\mathrm{B}$ & $62 \pm 8$ & $25 \pm 5$ & $15 \pm 4$ & ND & ND \\
\hline & $\mathrm{C}$ & ND & $78 \pm 4$ & $25 \pm 5$ & $172,687 \pm 12,642$ & $207,720 \pm 32,169$ \\
\hline \multirow[t]{3}{*}{ July } & A & $73 \pm 9$ & $86 \pm 3$ & $88 \pm 3$ & $58,006 \pm 2,530$ & $193,890 \pm 39,121$ \\
\hline & B & $83 \pm 7$ & ND & $10 \pm 4$ & ND & $256,110 \pm 66,926$ \\
\hline & $\mathrm{C}$ & ND & ND & $0 \pm 0$ & ND & $31,530 \pm 4,4465$ \\
\hline \multirow[t]{3}{*}{ August } & A & ND & ND & $89 \pm 4$ & ND & $5,703 \pm 1,384$ \\
\hline & B & ND & $45 \pm 5$ & $14 \pm 3$ & $55,375 \pm 16,283$ & $3,675 \pm 525$ \\
\hline & $\mathrm{C}$ & ND & ND & $4 \pm 2$ & ND & $1,992 \pm 514$ \\
\hline
\end{tabular}

\footnotetext{
a Means \pm standard error of the mean. Percent infected means based on 15, 25, and 25 observations in 2001, 2002, and 2003, respectively. Means of number of conidia based on four observations. Mummies were dried berries from the previous year. $\mathrm{ND}=$ not determined.

${ }^{\mathrm{b}}$ Locations were 300 to $400 \mathrm{~m}$ apart and along the perimeters of Mid-Columbia Agricultural Research and Extension Center pear orchards, about $5 \mathrm{~m}$ from the nearest trees.
} 
thecia were observed in the orchard or the laboratory.

\section{DISCUSSION}

Weeds and other orchard vegetation usually are mowed starting in spring, about the time that conidia were observed on germinating sclerotia in the present study. $B$. cinerea was capable of colonizing and persisting in tissue pieces of all six weed species in this study until pear harvest in early September, but levels of natural infestation of orchard ground cover clippings by $B$. cinerea have not been determined. Pear fruit become infested with $B$. cinerea, with infection occurring during or shortly after harvest (16). A significant relationship has been observed between the concentration of spores of $B$. cinerea on the fruit surface at harvest and the incidence of gray mold developing in cold storage (17). If colonization and persistence of $B$. cinerea clearly was greater on certain weeds, these could be targeted for specific removal from pear orchards. However, our results agree with the general observation that $B$. cinerea is capable of colonizing almost any of the Dicotyledones and many of the Monocotyledones (11). The genera Taraxicum and Poa are listed as hosts of $B$. cinerea, but the remaining four weed genera in this study are not listed as hosts (10).

Wild blackberry mummies appear to be a source of inoculum of $B$. cinerea. Over 2,000 conidia per mummy commonly were found in August prior to pear harvest, and up to $89 \%$ of mummies were infected at this time. In addition, infection and sporulation was observed on fresh berries in 2 of 3 years. Infection of fresh berries appeared to be related to occurrence of rain. Wild blackberries are common at the borders of pear orchards close to the Cascade Mountains in the Hood River and Willamette Valleys of Oregon (13) and the White Salmon area of Washington. They are less common in the drier Washington districts of Yakima and Wenatchee. Removal of wild blackberry bushes should reduce inoculum of $B$. cinerea in nearby pear orchards, but additional research is necessary to demonstrate this relationship.

Sclerotia formed on naturally infected pear fruit on the orchard floor in late November to early December. Over $90 \%$ of these sclerotia were viable the following season, but viability of sclerotia produced in inoculated fruit, then overwintered in the orchard, was usually less than $50 \%$. Survival of sclerotia of $B$. cinerea is moisture and temperature dependent. Only $10 \%$ survived for 8 months in unsterile vineyard soil in the laboratory at $22^{\circ} \mathrm{C}$ and $30 \%$ soil moisture (19). In the current study, naturally infected fruit had become completely decomposed by spring, and sclerotia were mixed into the top layer of debris and litter. In contrast, inoculated fruit in nylon mesh in wire baskets were still intact throughout spring and early summer, and sclerotia in this fruit may have been more exposed to fluctuating temperature and moisture levels, resulting in lower viability.

Under field conditions, sporogenic germination of sclerotia of $B$. cinerea is the most frequent method and occurs mostly in spring and autumn (5). We observed considerable sporogenic germination in both the orchard and laboratory. In the orchard, germination occurred in spring, but none was observed in summer or autumn.

Most isolates of $B$. cinerea are heterothallic; that is, they are self-sterile (9). A detailed protocol has been developed for spermatization of sclerotia to produce apothecia in the laboratory (8). We used 28 isolate pairings for fruit inoculation and sclerotia production to increase the possibility of apothecial production when fruit with sclerotia were placed in the orchard. However, all germination of these sclerotia, as well as naturally produced sclerotia, was myceliogenic or sporogenic, and apothecia appear to be rare or nonexistent in pear orchards.

In summary, sclerotia form in pear orchards in late autumn to early winter on infected fruit on the orchard floor. Sclerotia germinate in spring, and conidia can

Table 4. Production of sclerotia on pear fruit inoculated with pairs of isolates of Botrytis cinere $a^{\text {a }}$

\begin{tabular}{|c|c|c|c|c|c|c|c|}
\hline \multirow{2}{*}{\multicolumn{2}{|c|}{ Isolate A }} & \multirow{2}{*}{\multicolumn{2}{|c|}{ Isolate B }} & \multicolumn{4}{|c|}{ Number of sclerotia per fruit ${ }^{b}$} \\
\hline & & & & \multicolumn{2}{|c|}{2000} & \multicolumn{2}{|c|}{2001} \\
\hline ID & Sclerotia $^{c}$ & ID & Sclerotia $^{c}$ & d'Anjou & Bartlett & d'Anjou & Bartlett \\
\hline 104 & - & 106 & + & 50 & 327 & ND & ND \\
\hline 104 & - & 107 & + & 34 & 322 & ND & ND \\
\hline 104 & - & 203 & - & 10 & 222 & ND & ND \\
\hline 202 & + & 205 & + & 12 & 315 & 19 & 85 \\
\hline 202 & + & 203 & - & 8 & 129 & 7 & 58 \\
\hline 202 & + & 402 & + & 1 & 284 & 37 & 83 \\
\hline 205 & + & 402 & + & 62 & 185 & 14 & 90 \\
\hline 205 & + & 415 & - & 40 & 196 & 7 & 127 \\
\hline 537 & - & 538 & + & 39 & 291 & 38 & 68 \\
\hline 537 & - & 562 & + & 89 & ND & 35 & 91 \\
\hline 537 & - & 1038 & - & 4 & ND & 47 & 98 \\
\hline 1040 & + & 832 & + & 53 & ND & 15 & 98 \\
\hline 1040 & + & 835 & - & 38 & ND & 12 & 43 \\
\hline 2285 & + & 106 & + & 101 & ND & ND & ND \\
\hline 2285 & + & 202 & + & 15 & 67 & 9 & 93 \\
\hline 2285 & + & 415 & - & 48 & ND & 8 & 75 \\
\hline 2356 & + & 832 & + & 33 & 209 & 34 & 17 \\
\hline 2356 & + & 537 & - & 15 & 271 & 0 & 102 \\
\hline 2388 & - & 107 & + & 45 & 303 & 23 & 29 \\
\hline 2388 & - & 1038 & - & 4 & 116 & 0 & 80 \\
\hline 2388 & - & 2412 & + & 0 & 44 & 0 & 0 \\
\hline 2356 & + & 1048 & + & 5 & 176 & ND & ND \\
\hline 2412 & + & 2346 & + & 46 & 223 & ND & ND \\
\hline 2412 & + & 106 & + & 29 & 273 & ND & ND \\
\hline 205 & + & 401 & + & ND & 346 & 4 & 32 \\
\hline 2412 & + & 2356 & + & ND & ND & 0 & 23 \\
\hline 2412 & + & 811 & + & ND & ND & 4 & 33 \\
\hline 1040 & + & 811 & + & ND & ND & 33 & 143 \\
\hline Mean $^{\mathrm{d}}$ & $\ldots$ & $\ldots$ & $\ldots$ & $33 \pm 5$ & $226 \pm 21$ & $17 \pm 3$ & $70 \pm 8$ \\
\hline
\end{tabular}

${ }^{a}$ Isolates 202, 203, and 205 from Mount Adams, WA; isolates in 2000 series from Wenatchee, WA; all other isolates from Hood River, OR.

${ }^{\mathrm{b}}$ Values are means of triplicate fruit inoculations of each pairing. ND $=$ not determined.

${ }^{c}$ Sclerotia on acidified potato dextrose agar (APDA) medium for individual isolates.

${ }^{\mathrm{d}}$ Mean \pm standard error of the mean.

Table 5. Viability of sclerotia on pear fruit inoculated with pairs of isolates of Botrytis cinerea and overwintered on the orchard floor

\begin{tabular}{lccccc}
\hline & \multicolumn{5}{c}{ Sclerotia germinated (\%) } \\
\cline { 2 - 3 } & \multicolumn{2}{c}{$\mathbf{2 0 0 1}$} & & \multicolumn{2}{c}{$\mathbf{2 0 0 2}$} \\
\cline { 2 - 3 } \cline { 5 - 6 } Month & d'Anjou & Bartlett & & d'Anjou & Bartlett \\
\hline March & $50 \pm 8$ & $59 \pm 8$ & & ND & ND \\
April & $44 \pm 3$ & $45 \pm 5$ & & ND & ND \\
May & $37 \pm 2$ & $31 \pm 2$ & & $25 \pm 6$ & $17 \pm 4$ \\
June & $25 \pm 1$ & $23 \pm 2$ & & $47 \pm 4$ & $35 \pm 3$ \\
July & $19 \pm 2$ & $20 \pm 2$ & & ND & ND \\
August & ND & ND & & $25 \pm 3$ & $22 \pm 5$ \\
September & ND & ND & & $5 \pm 3$ & $25 \pm 8$ \\
\hline
\end{tabular}

${ }^{a}$ Values are the mean \pm standard error of the mean of 28 isolate pairings, three fruit per pairing, six sclerotia per fruit. Sclerotia were removed from fruit tissue, surface sterilized, and plated on acidified potato dextrose agar. Germination was evaluated after $40 \mathrm{~h}$ at $22^{\circ} \mathrm{C} . \mathrm{ND}=$ not determined. 
colonize pieces of tissue of weed species common to pear orchards in Oregon. We also have observed infection and sporulation on Bartlett fruit dropped and left in the orchard during harvest, which occurs about 2 weeks before d'Anjou and Bosc harvest. Although infection of pear blossoms by $B$. cinerea occurred through calyx parts and resulted in latent infections that were responsible for calyx end decay in storage in South Africa (6) and California (21), we did not observe this phenomenon in Oregon (16). In addition to the above sources of inoculum, blackberry mummies and fresh blackberry fruit infected with $B$. cinerea also serve as sources of conidia at pear harvest. Conidia of $B$. cinerea are dispersed by air currents, in water, and by insects (12). Thus, an integrated approach is needed to deal with these multiple sources of potential inoculum and to control gray mold in cold storage. This approach may include removal of fallen fruit from the orchard immediately after harvest, reduction in weed growth in orchard row middles by using irrigation emitters that water only the trees or by using synthetic ground covers, and eliminating blackberry plants on orchard perimeters. Further study is needed to determine if this integrated approach would result in reduced fungicide usage.

\section{ACKNOWLEDGMENTS}

We thank the Fresh and Processed Pear Subcommittee for partial funding of the research.

\section{LITERATURE CITED}

1. Bertrand, P. F., and Saulie-Carter, J. L. 1978. The occurrence of benomyl-tolerant strains of Penicillium expansum and Botrytis cinerea in the Mid-Columbia region of Oregon and
Washington. Plant Dis. Rep. 62:302-305.

2. Bertrand, P. F., and Saulie-Carter, J. L. 1979. Postharvest decay control of apples and pears after immersion dumping. Ore. State Univ. Exp. Stn. Spec. Rep. 545.

3. Blanpied, G. D., and Purnasiri, A. 1968. Penicillium and Botrytis rot of McIntosh apples handled in water. Plant Dis. Rep. 52:865-867.

4. Bristow, P. R. 1991. Botrytis fruit rot (gray mold) and blossom blight. Pages 21-23 in: Compendium of Raspberry and Blackberry Diseases and Insects. M. A. Ellis, R. H. Converse, R. N. Williams, and B. Williamson, eds. American Phytopathological Society, St. Paul, $\mathrm{MN}$.

5. Coley-Smith, J. R. 1980. Sclerotia and other structures in survival. Pages $85-114$ in: The Biology of Botrytis. J. R. Coley-Smith, K. Verhoeff, and W. R. Jarvis, eds. Academic Press, London.

6. De Kock, S. L. and Holz, G. 1992. Blossomend rot of pears: Systematic infection of flowers and immature fruit by Botrytis cinerea. J. Phytopathol. 135:317-327.

7. Domsch, K. H., Gams, W., and Anderson, T. H. 1980. Compendium of Soil Fungi, Vol. 1. Academic Press, London.

8. Faretra, F., Antonacci, E., and Pollastro, S. 1988. Improvement of the techniques used for obtaining apothecia of Botryotinia fuckeliana (Botrytis cinerea) under controlled conditions. Ann. Microbiol. 38:29-40.

9. Faretra, F., Antonacci, E., and Pollastro, S. 1988. Sexual behavior and mating system of Botryotinia fuckeliana, teleomorph of Botrytis cinerea. J. Gen. Microbiol. 134:2543-2550.

10. Farr, D. F., Bills, G. F., Chamuris, G. P., and Rossman, A. Y. 1989. Fungi on Plants and Plant Products in the United States. American Phytopathological Society Press, St. Paul, $\mathrm{MN}$.

11. Jarvis, W. R. 1980. Taxonomy. Pages 1-18 in: The Biology of Botrytis. J. R. Coley-Smith, K. Verhoeff, and W. R. Jarvis, eds. Academic Press, London.

12. Jarvis, W. R. 1980. Epidemiology. Pages 219250 in: The Biology of Botrytis. J. R. ColeySmith, K. Verhoeff, and W. R. Jarvis, eds. Academic Press, London.

13. Johnson, K. B., Sawyer, T. L., and Powelson, M. L. 1994. Frequency of benzimidazole- and dicarboximide-resistant strains of Botrytis cinerea in western Oregon small fruit and snap bean plantings. Plant Dis. 78:572-577.

14. Lennox, C. L., and Spotts, R. A. 1997. Botrytis gray mold as a postharvest pathogen in ' $d$ ' Anjou' pear. Pages 93-95 in: Proc. 13th Annu. Wash. Tree Fruit Postharvest Conf. E. Kupferman, ed. Washington State Horticultural Association, Wenatchee, WA.

15. Lennox, C. L., and Spotts, R. A. 2003. Sensitivity of populations of Botrytis cinerea from pear-related sources to benzimidazoles and dicarboximide fungicides. Plant Dis. 87:645649.

16. Lennox, C. L., and Spotts, R. A. 2004. Timing of preharvest infection of pear fruit by Botrytis cinerea and the relationship to postharvest decay. Plant Dis. 88:468-473.

17. Lennox, C. L., Spotts, R. A., and Cervantes, L. A. 2003. Populations of Botrytis cinerea and Penicillium spp. on pear fruit and in orchards and packinghouses, and their relationship to postharvest decay. Plant Dis. 87:639-644.

18. Mansfield, J. W. 1980. Mechanisms of resistance to Botrytis. Pages 181-218 in: The Biology of Botrytis. J. R. Coley-Smith, K. Verhoeff, and W. R. Jarvis, eds. Academic Press, London.

19. Nair, N. G., and Nadtotchei, A. 1987. Sclerotia of Botrytis as a source of primary inoculum for bunch rot of grapes in New South Wales, Australia. J. Phytopathol. 119:42-51.

20. Pierson, D. F., Ceponis, M. J., and McColloch, L. P. 1971. Market diseases of apples, pears, and quinces. Agric. Handb. 376. U. S. Dep. Agric. Washington, D.C.

21. Sommer, N. F., Buchanan, J. R., Fortlage, R J., and Bearden, B. E. 1985. Relation of floral infection to Botrytis blossom-end rot of pears in storage. Plant Dis. 69:340-343.

22. Spotts, R. A., and Cervantes, L. A. 1986 Populations, pathogenicity, and benomyl resistance of Botrytis spp., Penicillium spp., and Mucor piriformis in packinghouses. Plant Dis. 70:106-108. 